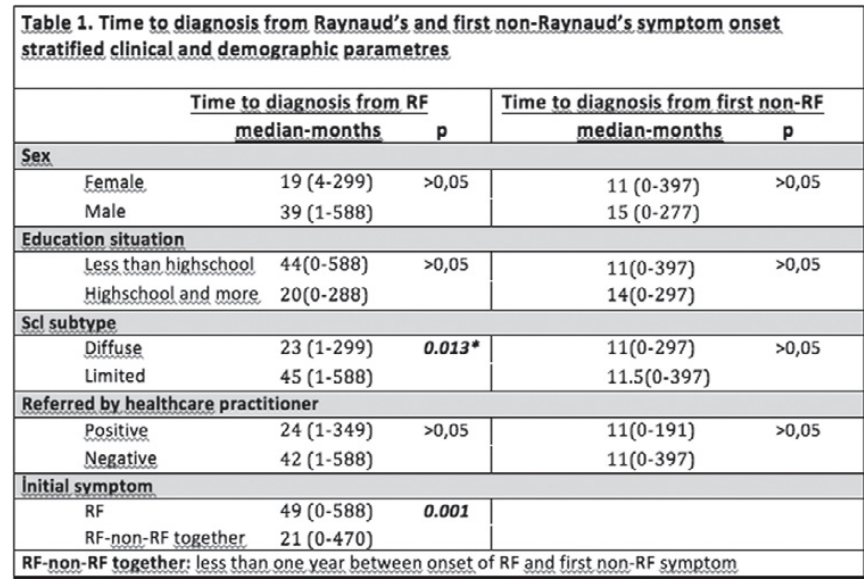

Conclusions: Time to diagnosis from onset of RF is significantly shorter in diffuse SSc. Although mRS is typically higher in diffuse SSc, no correlation has been found between mRS and time to diagnosis. Therefore, duration of diagnosis may be influenced by internal organ involvement and other complications rather than skin changes due to lack of awareness of physicians about SSc related early skin changes. Referral to a proper physician by a familier healthcare practitioner decreased the number of physicians attending till the diagnosis, although it did not affect the time to diagnosis.

Disclosure of Interest: None declared

DOI: 10.1136/annrheumdis-2017-eular.4645

\section{AB0659 ASSOCIATION BETWEEN -12518A/G GENE POLYMORPHISM ENCODING MONOCYTE CHEMOATTRACTANT PROTEIN 1 (MCP-1) AND SERUM LEVEL OF C-REACTIVE PROTEIN IN DIFFERENT CLINICAL AND SEROLOGICAL PHENOTYPES OF SYSTEMIC SCLEROSIS IN THE RUSSIAN COHORT OF PATIENTS}

M. Krylov, L. Ananieva, O. Koneva, M. Starovoytova, O. Desinova

O. Ovsaynnikova, E. Samarkina, A. Novikov, E. Aleksandrova. V. A. Nasonova Research Institute of Rheumatology, Moscow, Russian Federation

Background: Immune system activation with associated up-regulation in the production of extra-cellular matrix proteins by fibroblasts are known specific features in the pathogenesis of systemic scleroderma (SSc). Most recent data indicate that MCP-1 and MCP-3 chemokines from the family of monocyte chemoattractant proteins are also involved into SSc pathogenetic process. Creactive protein (CRP) is known as the marker of acute-phase inflammation. The association between increased CRP levels and SSc clinical and serological parameters has been reported recently.

Objectives: To study the association between $-2518 \mathrm{~A} / \mathrm{G}$ gene polymorphism, encoding MCP-1, and CRP levels in different clinical SSc phenotypes in the Russian cohort of pts.

Methods: PCR-RFLP method was used to identify MCP-1 genotype in 81 SSc pts aged $49,4 \pm 12,6$ years, with mean SSc duration $11,1 \pm 9,0$ years. CRP concentrations were measured with highly sensitive immunoturbidimertry method. Results: CRP levels were correlated with MCP-1 genotypes in pts with limited (IcSSc) and diffuse (dcSSc) phenotypes, with interstitial lung disease (ILD+), with SSc duration $>3$ years, with increased CRP level $(>5 \mathrm{mg} / \mathrm{L})$, with positive antibody titers to DNA topoisomerase I (ATA+) and antibody to centromeres (ACA+). A total cohort analysis showed that carriers of -2518AA genotype had higher mean CRP level versus $G$ allele carriers $(12,6 \pm 7,5 \mathrm{mg} / \mathrm{L}$ vs $4,9 \pm 4,8 \mathrm{mg} / \mathrm{L}$, respectively, $p=0,009)$, although similar trend was found in dcSSc phenotype $(16,4 \pm 19,5 \mathrm{mg} / \mathrm{L}$ vs $6,1 \pm 4,4 \mathrm{mg} / \mathrm{L}$, respectively, $p=0,040)$. In pts with $-2518 \mathrm{AA}$ genotype and SSc duration $>3$ years mean CRP level was significantly higher than in $\mathrm{G}$ allele carriers $(1,1 \pm 16,7 \mathrm{mg} / \mathrm{L}$ vs $4,5 \pm 4,4 \mathrm{mg} / \mathrm{L}$, respectively, $p=0,025)$. In (ILD+) and (ATA+) subgroup pts with -2518AA genotype demonstrated higher mean CRP levels as compared to $G$ allele carriers $(12,4 \pm 15,6 \mathrm{mg} / \mathrm{L}$ vs $5,5 \pm 5,1 \mathrm{mg} / \mathrm{L}$, respectively, $p=0,018$; and $17,6 \pm 20,9 \mathrm{mg} / \mathrm{L}$ vs $5,5 \pm 5,5 \mathrm{mg} / \mathrm{L}$, respectively, $p=0,010)$. CRP levels (>5 mg/L) were found in $31(38 \%)$ pts and were significantly different between AA genotype carriers and $G$ allele carriers $(27,4 \pm 19,2 \mathrm{mg} / \mathrm{L}$ vs $10,4 \pm 3,8 \mathrm{mg} / \mathrm{L}$, respectively, $p=0,003)$. No associations between genetic variations in the $M C P-1$ gene and CRP levels in IcSSc phenotype, SSc duration $<3$ years, CRP levels $<5 \mathrm{mg} / \mathrm{L}$ and $(\mathrm{ACA}+)$ pts were established.

Conclusions: Our data demonstrate that $-2518 \mathrm{~A} / \mathrm{G} M C P-1$ gene polymorphism is closely associated with CRP levels, thus, it can be considered as a new marker, reflecting the severity of the disease and unfavorable SSc prognosis.

Disclosure of Interest: None declared

DOI: 10.1136/annrheumdis-2017-eular.3130

\section{AB0660 CHARACTERISTICS OF AL-I LIGHT-CHAIN AND AMYLOID A DEPOSITION IN PROGRESSIVE SYSTEMIC SCLEROSIS - A COMPARATIVE POSTMORTEM CLINICOPATHOLOGIC STUDY OF 12 PATIENTS}

M. Bély ${ }^{1}$, Á. Apáthy ${ }^{2} .{ }^{1}$ epartment of Pathology, Policlinic of the Order of the Brothers of Saint John of God; ${ }^{2}$ Department of Rheumatology, St. Margaret Clinic Budapest, Budapest, Hungary

Background: Different types of amyloid deposits may be present in systemic sclerosis (SSc), as consequences (complications) of basic or associated diseases. Objectives: The aim of this study was to determine the type, prevalence and extent of amyloid deposits on different tissue structures in various organs in SSc. Methods: We studied histopathologically 12 SSc patients (females 11, average age: 54.82 years, range $66-32$, onset of SSc: 48.86 , average disease duration: 6.43 years; one male, age 65.0 years at death, onset of SSc and average disease duration not known, who died at the National Institute of Rheumatology. SSc was diagnosed clinically according to the criteria of the ACR [1]. In 1 (8.0\% of 12) 67 year old female patient (onset of SSc: 66 years, disease duration: 1 year) SSc was accompanied by B-cell lymphoma and complicated by systemic AL-I light-chain amyloidosis. In 1 (8.0\% of 12) 53 year old female patient (onset of SSc: 41 years, disease duration: 12 years) SSc was complicated by systemic amyloid $A(\mathrm{aA})$ deposition.

Amyloid deposits on different tissue structures [arteriole, small artery, medium size artery, venule, small vein, medium size vein, interstitial collagen fiber, reticulin fiber (collagen IV), and nerve] of 6 organs [heart, lungs, kidney, gastrointestinal tract, skin and brain] were determined histologically. The extent of amyloid deposition was evaluated by semi-quantitative, visual estimation on a 0 to 3 plus scale, based on the number of involved tissue structures per light microscopic field [2].

The prevalence and extent of amyloid-I light-chain and amyloid A deposits on different tissue structures were compared by Student (Welch) t-probe.

Results: The involvement of different tissue structures (prevalence in \%) and the average extent of AL-I light-chain and amyloid A deposits (absolute value) are summarized in Table 1.

Table 1

\begin{tabular}{lcccccc}
\hline Tissue structures & $\begin{array}{c}\text { SSc-I } \\
\text { Prevalence } \\
\text { in \% }\end{array}$ & $\begin{array}{c}\text { SSc-aA } \\
\text { Prevalence } \\
\text { in } \%\end{array}$ & $\mathrm{p}<$ & $\begin{array}{c}\text { SSc-I } \\
\text { Average } \\
\text { extent }\end{array}$ & $\begin{array}{c}\text { SSc-aA } \\
\text { Average } \\
\text { extent }\end{array}$ & $\mathrm{p}<$ \\
\hline Arteriole & 83,33 & 66,67 & 0,2749 & 2,00 & 1,33 & 0,1709 \\
Small artery & 83,33 & 66,67 & 0,1709 & 2,17 & 1,00 & 0,0414 \\
Medium size artery & 83,33 & 66,67 & 0,1520 & 2,33 & 0,67 & 0,0090 \\
Interstitial collagen & 66,67 & 50,00 & 0,2998 & 0,83 & 0,83 & 0,5000 \\
Medium size vein & 50,00 & 50,00 & 0,2735 & 1,17 & 0,50 & 0,1476 \\
Small vein & 50,00 & 50,00 & 0,5000 & 0,58 & 0,50 & 0,4088 \\
Venule & 33,33 & 33,33 & 0,5000 & 0,33 & 0,33 & 0,5000 \\
Collagen IV & 33,33 & 16,67 & 0,2749 & 0,50 & 0,33 & 0,3671 \\
Nerve & 0,00 & 0,00 & & 0,00 & 0,00 & \\
Average/Structure & 53,70 & 44,44 & 0,232 & 1,10 & 0,61 & 0,075 \\
\hline
\end{tabular}

Conclusions: In SSc patients the prevalence and extent of I light-chain and amyloid A deposits on different tissue structures changed parallel.

The higher prevalence and extent of I light-chain deposits in contrast to amyloid A may be explained with qualitative differences of I light-chain and amyloid A; I light-chain seems to have greater affinity for tissues than amyloid $A$ protein.

Infiltration of the vessel walls - regarding the amount of I light-chain and amyloid A deposits in arterioles and arteries in contrast to the veins - showed a converse tendency in SSc patients with AL-I or AAa. This may be related to sluggish blood flow or stasis (backward congestion and accumulation of circulating precursors) in both diseases.

\section{References:}

[1] van den Hoogen F et al: Ann Rheum Dis 2013; 72:1747-1755 doi: 10.1136/ annrheumdis-2013-204424.

[2] Bély M, Apáthy Ágnes: Clinical pathology of rheumatoid arthritis. 1-440 pp. Akadémiai Kiadó, Budapest 2012 http://www.akkrt.hu.

Disclosure of Interest: None declared

DOI: 10.1136/annrheumdis-2017-eular.1222

\section{AB0661 ORAL HEALTH-RELATED QUALITY OF LIFE MEASURED WITH OHIP 49 HIGHLY CORRELATES WITH DISEASE ACTIVITY AND SEVERITY IN SYSTEMIC SCLEROSIS PATIENTS}

K. Parat ${ }^{1}$, M. Radić ${ }^{2}$, K. Borić ${ }^{2}$, D. Perković ${ }^{2}$, D. Biočina Lukenda ${ }^{1}$,

D. Martinović Kaliterna ${ }^{2} .{ }^{1}$ Department of Oral Medicine and Periodontology, Study of Dental Medicine, School of Medicine, University of Split; ${ }^{2}$ Division of Rheumatology and Clinical Immunology, Center of excellence for Systemic Sclerosis in Croatia, University Hospital Split, Split, Croatia

Background: Systemic sclerosis (SSc) is associated with decreased saliva production and interincisal distance, more missing teeth, and periodontal disease. Orofacial manifestations of SSc contribute greatly to overall disease burden and still are regularly overlooked and under-treated. Previous studies did not confirm correlation between disease severity and oral health-related quality of life in SSc patients. 